\title{
Soft news i 2007-valgkampen: Balanceret, men ukritisk snak om mennesker i politik
}

\author{
AF CHRISTIAN ELMELUND-PRASTEKAE, \\ LOUISE MÜLLER \& LOUISE NOWAK RASMUSSEN
}

Denne artikel undersøger, hvordan soft news-programmer på tv behandlede politikere i 2007-valgkampen. Vi forventer en marginal mediebonus til regeringen og dens støttepartier i forhold til oppositionen. Vi forventer også, at indslagene handlede om politikerne som personer og i mindre grad om politik og processuelle forhold. Endelig forventer vi, at programmerne anlagde en positiv tone overfor de medvirkende. Studiet bygger på en kvantitativ indholdsanalyse af 52 indslag i de tre uger op til valget. Vi finder støtte til vores teoretiske forventninger, og konkluderer derfor, at de undersøgte programmer stort set balancerer de to blokke, at de er meget positive overfor de medvirkende, og at de i overvejende grad fokuserer på politikernes private liv frem for deres politik.

\section{Indledning}

Nyhedsmedierne spiller en central demokratisk rolle i medialiserede samfund som det danske (Hjarvard, 2008; Mazzoleni \& Schulz, 1999; Strömbäck, 2008). I en tid hvor kommunikationen mellem vælgere og politikere i al væsentlighed sker via medierne, har samfundsforskningen en vigtig opgave i at kortlægge, forklare og diskutere nyhedsjournalistikkens anatomi. Hvor litteraturen diskuterer eventuelle negative effekter af fænomener som tabloidisering (Esser, 1999), amerikanisering (Negrine \& Papa- 
thanassopoulos, 1996) og andre degenerationsprocesser (Patterson, 1994), er den gode samfundsmæssige nyhed, at der i dag bliver produceret langt flere og mere forskelligartede nyheder end for blot én generation siden: Hvor Danmark inden bruddet på DR's fjernsynsmonopol i 1988 havde én tv-avis, én radioavis og en håndfuld kvalitetsaviser, findes der i dag en række forskellige nyhedsprogrammer alene på DR, ligesom både DR og TV2 i stigende grad skræddersyr særlige nyhedsprogrammer til særlige seergrupper. Vi har samtidig nærmest ubegrænset adgang til konstant opdaterede nyheder på internettet, på TV2 News og DR Update. Endelig går de nyhedsformidlende medier nye veje for at få fat i målgrupper, der ikke tidligere havde noget stort nyhedsforbrug. Aktualitetsprogrammer og talkshows som Eleva2eren har været kendt længe, men egentlige soft news-programmer som Go' morgen Danmark og Aftenshowet er forholdsvise nye opfindelser (Hjarvard, 1999). Fremvæksten af sådanne programmer kan forstås i et bredere kultursociologisk perspektiv, som sætter fokus på, hvad man kan betegne som en ny politisk stil - en stil der særligt kendetegnes ved en øget blanding af det politiske og populærkulturen (se fx. Corner \& Pels, 2003).

De mange nye informationskanaler og formater kan være med til at give vælgerne et nyt grundlag for at tilegne sig viden om politiske aktører og deres budskaber. De kan omvendt også være med til at forringe den demokratiske samtale, hvis de systematisk undlader at forholde sig til substantielle politiske problemstillinger for i stedet at dyrke personligheder, sensationer og enkeltsager. En forudsætning for at kunne tage kvalificeret stilling i denne debat er selvsagt konkret viden om, hvad de forskellige former for nyhedsjournalistik indeholder. Hvor en række studier har studeret den traditionelle „hårde“ nyhedsjournalistik (fx. Bro et al., 2005; Hopmann et al., Forthcoming), mangler vi systematisk viden om den nyere, „bløde“ genre. Formålet med nærværende artikel er derfor at undersøge, hvordan udvalgte programmer (Go' morgen Danmark, Go' aften Danmark og Aftenshowet) i en udvalgt periode (de tre uger op til folketingsvalget i 2007) behandler politiske aktører.

Artiklen er opdelt i fem hovedafsnit. Først giver vi en kort beskrivelse af soft news-genren. Dernæst opstiller vi en analyse- 
ramme og formulerer en række hypoteser - for i det tredje afsnit at diskutere metodiske spørgsmål og valg af empiri. Analysen foretages i det fjerde afsnit, mens det sidste afsnit rummer en konklusion og en diskussion af resultaterne i et samfundsmæssigt perspektiv.

\section{Soft news-genren}

Soft news-genren har sine rødder i de såkaldte Happy News-programmer, som dukkede op på amerikansk tv i 1970'erne. Efterfølgende kunne der også i Danmark ses eksempler på denne programtype, da DR lancerede programmerne Kanal 22 (1979) og Lørdagskanalen (1982), der ses som forløbere til nutidens soft news-programmer (Jensen, 2001). Det var dog først i slutningen af 1980'erne, at den nye, underholdende journalistik for alvor vandt indpas i Skandinavien, da genren tidligere "was simply too culturally remote, both for producers/journalists and the public" (Dahlgren, 1995). I en dansk kontekst blev bruddet på DR's fjernsynsmonopol i 1988 et vendepunkt. Monopolbruddet skabte et nyt medielandskab, hvor der blev sat nye standarder og krav til journalistikken om at være konkurrencemindet og fokuseret på seertække. Programmerne skulle nu udfylde både informative og underholdende funktioner i forhold til seerne (Bruun, 1999). TV2's bud på journalistisk underholdning blev Eleva2eren, som hurtigt blev populær blandt seerne, og dermed var vejen banet for soft news-gennembruddet i Danmark (Jensen, 2001).

Soft news-begrebet er generelt løst defineret, men i samfundsvidenskabelige analyser henvises der ofte til Brants (1998), som opstiller et kontinuum, hvor de to modpoler udgøres af henholdsvis information og underholdning. På informationssiden findes programmer med „hård“ og seriøs nyhedsdækning, som oftest omhandler politik og faktuelle samfundsforhold. I den anden ende af skalaen, fokuseres der på livsstil, fornøjelse og sladder. Begrebet soft news defineres som midtpunktet mellem de to ekstremer. I fin forlængelse af en sådan begrebsliggørelse giver Patterson (2000) et bud på, hvad der adskiller soft newsgenren fra den traditionelle nyhedsdækning: "Soft news is typically more sensational, more personality-centered, less time- 
bound, more practical, and more incident-based than other news". I en dansk sammenhæng har Hjarvard (1999) beskrevet genren, og han lægger vægt på nærhedsbegrebet. Programmerne skaber ofte en parallelverden til publikums hverdagsliv og præsenterer dermed politiske nyheder i et anderledes lys end de traditionelle nyhedsudsendelser, hvor underholdningsværdien er mindre afgørende. Målet er ganske enkelt at sætte seerne i stand til at identificere sig med de politiske personer.

Endelig understreger Hjarvard (1999) genrens relevans set fra politikernes side. Politikernes stigende interesse for underholdningsprægede programmer skyldes det forhold, at de hér har muligheden for at vise en mere menneskelig profil overfor vælgeren, hvilket er et væsentligt element i moderne valgkampagner. Bruun (1999) kalder ligefrem den bløde nyhedsgenre „en perfekt platform for politikernes imagepleje og valgkamp“. Dette aspekt er også diskuteret i den internationale litteratur, hvor kommunikations- og journalistikforskere sætter spørgsmålstegn ved, om de blødere programtyper i det hele taget bør gå ind på det politiske område, fordi de medvirkende politikere kan have en klar egeninteresse $\mathrm{i}$ at anvende programmerne som en ucensureret taleplatform i valgkampe (Baum, 2003; Brants, 1998; Brants \& Neijens, 1998; Patterson, 2000; Plasser, 2005).

\section{Analyseramme}

Eksisterende analyser af politisk indhold i tv-mediet begrænser sig ofte til hard news. Den forskningsmæssige interesse for mediernes dækning af politik intensiveres op til valg, og typisk interesserer sådanne studier sig for, hvilke politiske emner der er på mediernes dagsorden, hvorvidt medierne favoriserer bestemte politikere og partier, og hvordan medierne vinkler de politiske historier (fx. Hopmann et al., Forthcoming; Semetko, 1996; Shoenbach et al., 2001). Idet vi ønsker at studere et felt, der er forholdsvis uudforsket, vælger vi at orientere analysen mod de aspekter af dækningen, som allerede er undersøgt i andre typer af nyhedsjournalistisk. Overordnet interesserer vi os således dels for, om soft news-programmerne på den ene eller anden facon favoriserer nogle partier og politikere på bekostning af andre. 
Dels interesserer vi os for karakteren af selve indholdet i de soft news-indslag, som omhandler politiske aktører. Vi ønsker med andre ord at studere genren i et samfundsmæssigt perspektiv ved at sætte fokus på eventuel politisk skævvridning og programmernes informationsniveau forud for et valg. I det følgende opstiller vi en analyseramme, der sætter fokus på tre forskellige aspekter af de analyserede programmers indhold.

\section{Let ubalanceret medieopmærksomhed}

Et tilbagevendende spørgsmål i moderne journalistik og mediekritik er, hvorvidt medierne systematisk favoriserer enten den ene eller anden fløj i dansk politik (Hopmann, 2009). I den internationale litteratur tales der i denne forbindelse om forskellige typer af såkaldte mediebonusser, som ikke nødvendigvis skyldes, at medier og journalister forsøger at hjælpe én side på bekostning af den anden. Walgrave \& de Swert (2002) viser således, at der er sammenhæng mellem en politikers position og den medieopmærksomhed, vedkommende tiltrækker. Set i lyset af de klassiske nyhedsværdier virker dette ikke overraskende, idet regeringspartier og -politikere har magten og derfor både kan og bør stilles til ansvar for den førte politik. Samtidig er der en stor sandsynlighed for, at regeringspolitikernes forslag og ideer bliver til konkret politik, mens oppositionspolitikernes ditto i højere grad forbliver politisk retorik, fordi de netop mangler den politiske magt til at sætte handling bag ordene. Af den grund kan regeringer ganske enkelt være mere nyhedsværdige end oppositioner (se også fx. Brettschneider, 2002). Man kan i den sammenhæng skelne mellem tre typer af mediebonusser: Regeringspartibonus (ekstra medieopmærksomhed til regeringspartierne), kabinetbonus (ekstra medieopmærksomhed til de siddende ministre) og kanslerbonus (ekstra medieopmærksomhed til den siddende statsminister) (Walgrave \& de Swert, 2002).

Det skal dog nævnes, at disse mediebonussers størrelse varierer mellem lande med forskellige politiske systemer. Mediedækningen synes at være mere balanceret i lande, hvor den politiske magt er spredt mellem flere partier og i lande, hvor regeringslederen per definition står svagt overfor lovgiverne. I sådanne systemer findes der ofte koalitions- og mindretalsregeringer, hvil- 
ket kan betyde, at selv små oppositionspartier bliver afgørende i den regeringsdannelsesproces, der finder sted efter endt valgkamp. Når oppositionen som aktør således bliver mere politisk indflydelsesrig, bliver den også mere journalistisk interessant, hvilket mindsker de omtalte mediebonusser (Hopmann, 2009). Således har det vist sig, at medieopmærksomheden i såvel Danmark (Hopmann et al., Forthcoming) som i Sverige, Norge og Holland (Asp, 2006; Shoenbach et al., 2001) er nogenlunde ligeligt fordelt mellem regering og opposition i nationale valgkampe. På denne baggrund er det vores forventning, at

- Den siddende regering har en marginalt større synlighed end oppositionen (H1a)

- De siddende ministre optrceder oftere end andre politikere (H1b)

- Den siddende statsminister optrceder marginalt oftere end oppositionens statsministerkandidat (H1c)

\section{Positiv tone}

Ét er synligheden af bestemte aktører i en valgkampssituation. Noget andet er mediernes fremstilling af dem. I forbindelse med valgkamp er det interessant at undersøge, hvorvidt nogle partier dækkes mere eller mindre positivt end andre. En sådan tone-analyse er relevant af flere grunde; dels ligger neutralitetsnormen dybt i både danske og udenlandske journalister (Weaver, 1998; Wien, 2005), dels kan fremstillingen af politikere i medierne påvirke vælgernes vurdering af disse (Fournier et al., 2004; Ridout \& Franz, 2008). Journalisternes tone overfor politikerne kan dog også være interessant, selvom den ikke varierer fra parti til parti eller fra politiker til politiker. Alt efter hvilken rolle man mener, journalisten bør spille i samfundet, kan man argumentere for nødvendigheden af en mere eller mindre kritisk journalistik. Den klassiske „vagthund“ kontrollerer magthaverne og er dermed næsten automatisk skeptisk indstillet. Det samme kan siges om ,jagthunden“, der er opsøgende og bevidst søger konfrontation (Bro, 2008). Hvad end man foretrækker, er der ikke megen plads til en „skødehund“, der ukritisk bjæffer politikerne efter munden. Ud fra sådanne normative idealer kan man forvente, at journalisterne er kritiske overfor politikere, eller at de i det mindste ikke anlægger en positiv tilgang, der kunne forveksles med mikrofon- 
holderi. Således har eksisterende studier fundet en lille overvægt af negative historier i forhold til positive, når politiske aktører dækkes i hard news - dog er langt de fleste indslag neutrale og kan altså ikke siges at være til fordel eller ulempe for nogen af de involverede parter (Hopmann et al., Forthcoming; Patterson, 1997).

Imidlertid er soft news-genren forskellig fra de traditionelle hard news. Netop en positiv tone er et afgørende element i forsøget på at skabe et indbydende og familiært forum i den bløde nyhedsgenre. Det er derfor forventeligt, at der i denne type programmer er særlig opmærksomhed på at underholde og informere seeren i afslappende omgivelser og med en selskabelig tone (Hjarvard, 1999). Formålet med interviews i „snakkeprogrammerne" er således ikke at skabe konflikt, foretage afsløringer eller stille politikere til ansvar. Derimod er formålet at støtte den interviewede til at åbne op og tale om mere personlige aspekter af sit politikerliv uden stram redigering og hyppige afbrydelser (Bruun, 1999; Hjarvard, 1999). På denne baggrund forventer vi, at tonen overfor de medvirkende politikere $i$ de analyserede programmer hovedsagligt er positiv (H2).

\section{Fokus på personer}

Flere studier af både dansk og udenlandsk nyhedsdækning konkluderer, at en stor og muligvis stigende andel af indslag og artikler fokuserer på det politiske spil og på politikerne som personer frem for det egentlige politiske indhold i konkrete sager (Bro et al., 2005; Patterson, 1994; Plasser, 2005). Hensigtsmæssigheden af et sådan fokus kan naturligvis diskuteres, men det begrænser sig langt fra til den journalistiske dækning: Politik er formentlig helt generelt blevet mere personfokuseret gennem den seneste generation (Andersen \& Borre, 2007). Nogle forskere argumenterer endda for, at vælgernes stemmeafgivelse i højere grad bliver baseret på deres forhold til de politiske kandidater frem for et ideologisk bånd mellem vælger og partiapparat (Mancini \& Swanson, 1996). Det kan således ikke undre, at de politiske aktører bevidst forsøger at gå apolitiske veje i underholdningsprægede programmer i bestræbelserne på at vinde flest mulige stemmer (Brants \& Neijens, 1998). 
Givet soft news-genrens fokus på let identificerbare budskaber og det personlige nærvær, samt vælgernes, politikeres og mediernes generelle ønske om personlige historier forventer vi, at den personlige vinkling dominerer i forhold til vinklinger på politiske processer og konkrete politiske emner ( $\left.\mathrm{H}_{3}\right)$.

\section{Data og metode}

\section{Valg af empirisk materiale}

Analysen bygger på en kvantitativ indholdsanalyse af de i alt 42 udgaver af DR's Aftenshowet og TV2's Go' morgen, Danmark og Go' aften Danmark, der blev sendt under valgkampen forud for Folketingsvalget i 2007 (fra valgudskrivelsen den 24. oktober til valgdagen den 13. november). Vi har således valgt at fokusere på tv og fravalgt de bløde nyheder, der måtte findes i aviser, blade, magasiner, radio, internet og andre typer af medier. Vi har valgt tv-mediet, fordi DR's og TV2's programmer stadig formår at samle flere seere pr. udsendelse end andre medier - hvis der findes noget virtuelt forsamlingshus, som giver danskerne en fælles referenceramme, er og bliver det tv (Bro et al., 2005; Strömbäck, 2008). I forhold til eksempelvis USA har Danmark et beskedent udbud af programmer, der kan kategoriseres som soft news-programmer. Nok har vi samfundsorienterede talk shows som Clement Direkte, men de sendes typisk kun én gang om ugen, og da vi ønsker at studere soft news under valgkamp, har vi behov for daglige udsendelser. Derfor falder valget på de tre nævnte programmer. De tre programmer blev sendt alle hverdage under valgkampen (enkelte dage måtte Aftenshowet dog vige for DR's partipræsentationer) og enkelte søndage. Til selve analysen udvælger vi alene de indslag, hvori der medvirker en eller flere politiske aktører. På denne måde ekskluderes indslag om madopskrifter, kendte kulturpersoner og forskellige typer af forbrugeroplysning.

\section{Operationaliseringer}

En indholdsanalyse står og falder med dens kategorier (Berelson, 1952). Det er derfor centralt at definere hvilke variable, der kodes i analysen og ikke mindst, hvordan de bliver kodet. Til brug for det første sæt af hypoteser er det nødvendigt at kode dels parti- 
farven på de politikere, der optræder i de enkelte indslag; dels de optrædende politikeres position i deres respektive partier. Vi koder de enkelte aktører i den højest mulige kategori: Hvis eksempelvis en politiker både er partiformand og folketingsmedlem, kodes vedkommende som partiformand. Denne procedure er forholdsvis uproblematisk, eftersom der er tale om manifeste og let observerbare forhold.

Operationaliseringen af den dominerende tone i tv-indslagene kan være vanskelig, fordi tonen er en latent kvalitet ved indslaget, som ikke direkte kan aflæses. Vi vælger som udgangspunkt en simpel kategorisering, hvor vi vurderer, om det enkelte indslag samlet set er til fordel eller ugunst for den medvirkende politiker. Hvis det ikke er muligt at afgøre, findes der endelig en tredje, neutral kategori. Således koder vi et indslag som negativt, hvis det fokuserer på dårlige sager eller på anden vis stiller den interviewede i et dårligt lys. Da værten på Go' aften Danmark eksempelvis stillede kritiske spørgsmål til Naser Khader om hans påståede brug af sort arbejde, var der tale om et indslag med en negativ tone - Khader var i defensiven, og indslaget blev til en slags forsvarstale for den, i hans øjne, uberettigede anklage. Omvendt har vi kodet et indslag, hvor Anders Fogh Rasmussen blev udspurgt om sit første møde med sin hustru, som positivt, fordi det gav ham lejlighed til at fremhæve de personlige og mere følsomme sider af sig selv, han ofte er blevet kritiseret for at skjule.

Også analysen af vinklingen i de enkelte indslag forudsætter en vis grad af subjektiv vurdering. Vi arbejder derfor igen med en relativ enkel kategorisering af indslagenes generelle vinkling, ligesom vi følger en række eksisterende danske og udenlandske analysers opbygning: Således sondrer vi mellem politik-vinkling, person-vinkling og proces-vinkling. Politik-vinklede indslag defineres som indslag, der hovedsageligt handler om et politisk emne, et konkret tiltag eller bredere visioner. Person-vinklede indslag handler først og fremmest om interviewpersonernes eget liv, dagligdag, familie, lederegenskaber og andre personlige karaktertræk. Endelig handler proces-vinklede indslag om det politiske spil, fx. tolkninger af meningsmålinger, spekulationer om fremtidige partisamarbejder og interne stridigheder (jf. Bro et al., 2005). 


\section{Reliabilitetstest}

Inden det egentlige analysearbejde gik i gang, blev kodningsskemaet testet på et mindre antal "forsøgsudsendelser“ for at kontrollere, om det fungerede i praksis. I den forbindelse blev der tilføjet enkelte hjælpetekster og en ,andet“-kategori i vinklingsvariablen. Disse tiltag sigtede på at sikre undersøgelses reliabilitet, hvilken vi efter endt kodning har undersøgt. I den forbindelse har vi bedt tre trænede kodere om at genkode ti tilfældigt udvalgte indslag. Reliabilitetstesten behandler udelukkende variablene tone og vinkling fordi de, i modsætning til de to aktørvariable, behandler latent indhold og derfor har større risiko for at blive farvet af individuelle opfattelser hos forskellige iagttagere. Som målestok for overensstemmelsen mellem de forskellige kodere anvender vi software, der kan beregne Krippendorffs alpha (Krippendorff \& Hayes, 2007). Selvom der ikke er perfekt overensstemmelse mellem de tre koderes vurderinger, er alpha-niveauerne pæne (tone: $\alpha=0,74$; vinkel: $\alpha=0,75$ ). Krippendorff (2004) selv anbefaler, at alphaværdien skal være over o,8, men han mener også, at værdier helt ned til o,667 tillader, at man drager foreløbige konklusioner.

\section{Resultater}

At de undersøgte soft news programmer rent faktisk prioriterer aktualitetselementet i løbet af en valgkamp understreges af det faktum, at hele 52 indslag i de 42 analyserede enheder indeholdt politikere. I 2007-valgkampen var der således i gennemsnit godt et politisk indslag i hver eneste soft news-udsendelse. Tidsmæssigt svarer det samlet set til knapt syv en halv times fjernsyn. Den forholdsvis høje prioritering af politisk stof i de undersøgte programmer illustreres ligeledes af det faktum, at de analyserede indslag sædvanligvis lå først i udsendelserne og således havde karakter af tophistorier: Godt halvdelen af indslagene (27 ud af 52) var placeret som det første indslag, mens andre 19 (altså godt en tredjedel) var placeret som det andet indslag. På denne baggrund kan vi med solidt empirisk belæg konkludere, at politisk stof var 
en vigtig og integreret del af danske soft news-programmer anno 2007.

\section{Mediebonusser eller ej?}

For at kunne afgøre, om den siddende regering blev favoriseret, grupperer vi de enkelte partier i to alternative regeringsblokke. Til den borgerlige blok henregnes selvsagt Venstre og Det Konservative Folkeparti, men også både Dansk Folkeparti og Ny Alliance placeres i denne gruppe. Dansk Folkeparti er selvskrevet medlem af den borgerlige blok, da partiet har været fast støtteparti for regeringen siden 2001. Ny Alliance er vanskeligere at placere, da partiet først sent i valgkampen gjorde klart, hvilken statsministerkandidat det støttede op om. Partiet endte dog med at pege på Anders Fogh Rasmussen, hvorfor vi opfatter det som et borgerligt parti. Oppositionsblokken omfatter de resterende partier, der alle ønskede et regeringsskifte med Socialdemokraternes Helle Thorning-Schmidt som ny statsminister.

Da en række af de analyserede indslag rummede flere politiske aktører fra forskellige partier, er det nødvendigt at kvalificere oversigten. Ingen udsendelser indeholdt mere end fire politikere, men hér optrådte der altid to fra hver blok. I indslag med tre politikere var der altid mindst én politikere fra hver af blokkene med. Vi sondrer derfor mellem indslag med en ligelig fordeling af politikere (én eller to fra hver blok), indslag med en overvægt af den ene blok (to mod én) og indslag, som kun gav fjernsynstid til den ene af siderne (én eller to politikere fra samme blok).

Figur 1 viser, at langt de fleste indslag (39 ud af 52) var ensidige i den forstand, at de kun rummede politikere fra den ene politiske blok. Omvendt var disse indslag nogenlunde ligeligt fordelt mellem de to blokke, idet oppositionspolitikere optrådte i 17, mens politikere fra regeringsblokken optrådte i 22 indslag. Sidstnævnte blok havde således en mindre mediebonus i denne henseende. Det samme billede tegner sig, hvis man ser på den samlede sendetid fordelt på de to blokke. Ud af de i alt syv timer og 25 minutters fjernsyn, optrådte den borgerlige blok i tre timer og $58 \mathrm{mi}$ nutter, mens oppositionen var på skærmen i tre timer og 27 minutter. Den regeringsbærende blok havde altså en mediebonus på en halv time, hvilket må betegnes som en marginal bonus. ${ }^{1}$ 


\section{Figur 1}

Antal indslag fordelt på regerings- og oppositionsblokkene, alle indslag

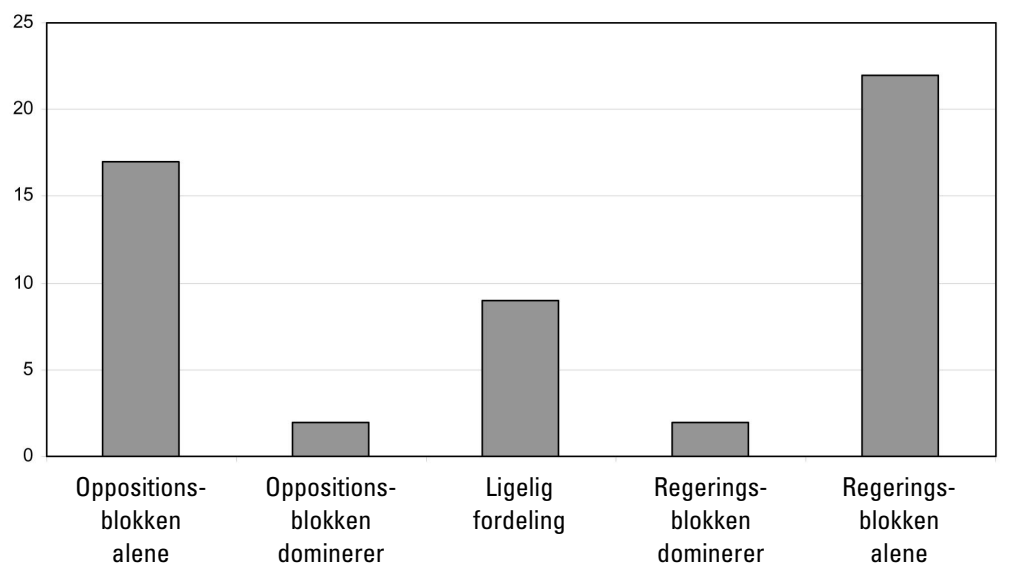

Konklusionen på denne del af analysen er derfor, at de to store blokke i dansk politik var nogenlunde afbalanceret i forhold til hinanden i de analyserede programmer. Dog kan der spores en lille regeringsblokbonus, hvorfor Hia bestyrkes af den empiriske analyse.

Vender man blikket mod den type af politikere, der optrådte i udsendelserne, finder man en klar overvægt af de indflydelsesrige af slagsen. Som det fremgår af figur 2, optrådte der i alt 73 politiske aktører i de 52 indslag (dog var nogle gengangere som eksempelvis de to statsministerkandidater, der deltog i flere udsendelser). Toppolitikere, betragtet som statsministerkandidater, ministre og partiformænd, optrådte samlet set 57 gange, hvorimod lavere rangerende politikere som almindelige folketingsmedlemmer, folketingskandidater og menige partimedlemmer kun optrådte 16 gange. Samtidig skal man have in mente, at der selvsagt findes langt flere politikere i den sidstnævnte gruppe end i den førstnævnte. Det står således klart, at politisk magt spillede en afgørende rolle for soft news-programmernes udvalg af politiske aktører.

Spørgsmålet er dernæst, om ikke også regeringsmagt i mere snæver forstand spillede ind? Svaret er ,ja, i nogen grad“: Hvor både den borgerlige regeringsblok og den socialdemokrati- 


\section{Figur 2}

Antal indslag (søjler) og minutter (punkter) fordelt på forskellige typer af politikere, alle indslag

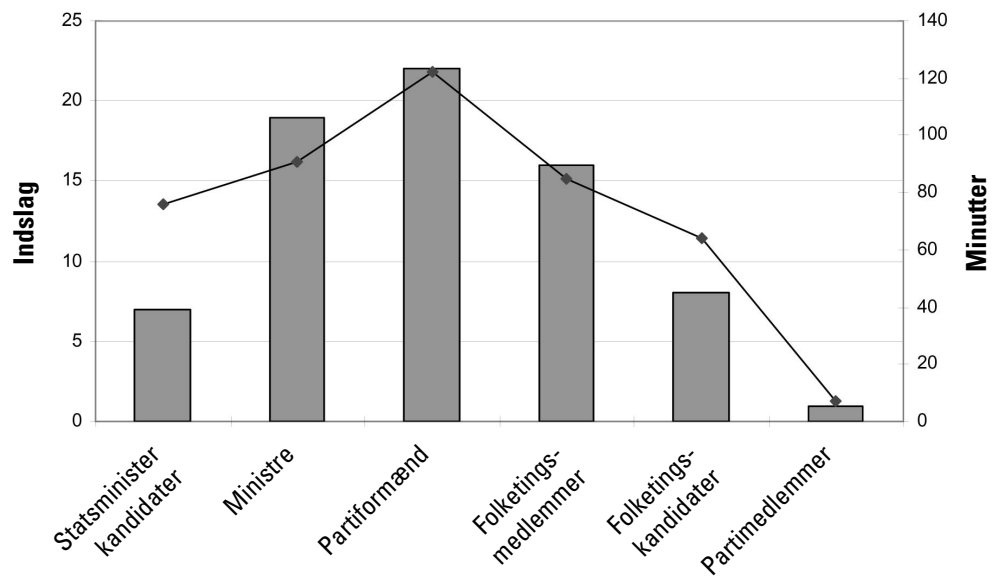

ske oppositionsblok havde statsministerkandidater og partiformænd, var det selvsagt kun regeringsblokken, der havde ministre. Disse ministre blev i et vist omfang modvejet af menige folketingsmedlemmer fra oppositionen, men selv hvis samtlige 16 menige medlemmer alle var fra oppositionen, slog de ikke ministre i antal (de optrådte nemlig 19 gange). Samme billede tegner sig, hvis man ser på den samlede tid, de enkelte grupper af politikere var på tv. Her skal der dog tages højde for, at der jævnligt optrådte politikere med forskellige positioner i det samme indslag. Når det var tilfældet, deler vi indslagets længde med antallet af politikertyper, så hver af grupperne tilskrives en proportional mængde tid. Hvis der medvirkede to ministre og to partiformænd tilskrives halvdelen af indslagets længde hver af grupperne „ministre“ og „partiformænd“. Dog skal det nævnes, at indslagene med de to statsministerkandidater var længere end andre, hvorfor de to kandidater udfyldte en ret stor andel (op mod en femtedel) af den samlede sendetid.

På baggrund af de beskrevne resultater kan vi konkludere to ting: For det første er vores hypotese (H1b) om, at siddende ministre havde en marginal mediefordel i forhold til andre ledende politikere bekræftet. For det andet er det tydeligt, at nyhedsvær- 
dien af politikere var tæt knyttet til deres politiske magt - selv i soft news-programmer. I vores resultater kan man måske endda se tegn på, at de analyserede programmer dækkede valgkampen som en slags præsidentvalg, eftersom de to statsministerkandidater fik relativt meget plads i forhold til andre partiledere.

Som sidste led i første del af vores analyse, zoomer vi nu ind på netop de to statsministerkandidater for at se, om den siddende kandidat, Anders Fogh Rasmussen, havde en mediemæssig fordel i forhold til sin udfordrer, Helle Thorning-Schmidt. Ser man udelukkende på det antal minutter, de to sad i tv-studierne, havde Fogh Rasmussen en fordel, da han var på godt ti minutter længere end Helle Thorning-Schmidt. Denne forskel skyldes dog udelukkende, at Fogh Rasmussen optrådte i fire indslag, mens Helle Thorning-Schmidt kun optrådte i tre. Da vi her har at gøre med meget få indslag skal man være varsom med at drage bastante konklusioner - den lille forskel kan skyldes rene tilfældigheder og er ikke nødvendigvis et bevis på en mediebonus til den siddende kandidat. Hypotese Hic finder således ikke empirisk støtte i nærværende analyse.

\section{Positiv tone?}

De to blokke i dansk politik ser altså ud til at være nogenlunde ligeligt behandlet i de undersøgte programtyper. Men hvordan ser det ud med tonen i dækningen? Igen skal det bemærkes, at der jævnligt optrådte flere politikere i samme indslag, men i sådanne tilfælde anlagde studieværterne samme tone overfor alle deltagere. Vi vælger derfor at analysere indslag frem for aktører i denne del af analysen.

Resultatet af den empiriske analyse støtter hypotese H2 (se tabel 1): Knap tre fjerdedele af indslagene (37 ud af 52) var positive overfor de politiske aktører. Andre 13 indslag var neutrale, og blot to anlagde en negativ tone over for de interviewede politikere. Samtidig står det klart, at der ikke er nævneværdige forskelle på den tone, studieværterne anlagde overfor henholdsvis den borgerlige og den socialdemokratiske blok.

Selvom vi havde en teoretisk givet forventning om, at soft news-programmer er mindre kritiske end hard news-programmer, betragter vi det som overraskende, at kun to indslag anlagde 
Tabel 1

Antal indslag i de tre analyserede programmer fordel efter tone

\begin{tabular}{lcccc}
\hline & Negativ & Neutral & Positiv & I alt \\
\hline Go' morgen Danmark & 1 & 9 & 9 & 19 \\
\hline Go' aften Danmark & 1 & 3 & 10 & 14 \\
\hline Aftenshowet & 0 & 1 & 18 & 19 \\
\hline I alt & 2 & 13 & 37 & 52 \\
\hline
\end{tabular}

en egentlig kritisk linje. Dette resultat forstærker argumentet om, at soft news-genren kan være et godt sted for politikerne at føre valgkamp - de bliver simpelthen ikke modsagt, udfordret eller på anden vis mødt med den kritiske journalistik, som de kender fra andre nyhedsmedier. Det skal dog nævnes, at vi i en supplerende analyse har fundet, at morgenprogrammet lavede markant flere neutrale indslag end de to aftenprogrammer (se tabel 1). Aftenshowet var mest positiv overfor politikerne, mens Go' aften Danmark ikke lå langt efter. Go' morgen Danmark var derimod markant mindre positiv, idet kun knapt halvdelen af programmets indslag kan karakteriseres som positive. Resten af indslagene var neutrale, på nær ét som var negativt. Således ligner morgenprogrammet på dette specifikke punkt de traditionelle tv-nyheder lidt mere end aftenprogrammerne.

\section{Fokus på personlighed?}

Sidste del af analysen fokuserer på den overordnede vinkling i de analyserede indslag, og igen finder vi støtte til hypotesen, H3: To tredjedele af indslagene (34 ud af 52) var vinklet på de medvirkende som personer, mens ti var vinklet over processen i valgkampen, mens kun fire handlede om politik. De fleste indholdsanalyser af traditionelle nyheder studerer indgående, hvilke emner medierne lader politikere komme til orde indenfor for derved at kunne afgøre, om medierne via deres emnevalg favoriserer bestemte partier (fx. Asp, 2006). En sådan emneanalyse giver selvsagt ikke megen mening i nærværende analyse grundet det forsvindende lille fokus på politik, hvorfor konklu- 
sionen må være, at soft news-programmerne ikke forfordelte nogle politikere.

I lighed med den ovenstående analyse af tonen, har vi også foretaget en supplerende analyse af vinklingen i morgen- og aftenprogrammerne. Igen viser der sig forskelle: Go' morgen Danmark brugte procesvinklen oftere end de andre to programmer faktisk har vi slet ikke fundet en sådan vinkling i Go' aften Danmark (se tabel 2). Samtidig var den smule politisk indhold, der trods alt blev diskuteret i de analyserede udsendelser, næste alle at finde i morgenprogrammet. Som en logisk konsekvens af disse fordelinger, fokuserede næsten alle aftenindslag på både DR og TV2 på de medvirkende som personer. Soft news-programmerne var således ikke bare gode platforme for politikernes kampagne, som konkluderet i forrige delanalyse - de var også ideelle platforme for politikernes imagekampagne. En kampagneform, som synes stadig vigtigere i et politisk system, hvor vælgerne beslutter sig sent i valgkampen, ofte skifter parti og stemmer på baggrund af enkeltsager frem for ideologisk overbevisning.

Hvis man sammentænker resultaterne for vinklings- og toneanalyserne, er det oplagt at undersøge, om der findes en sammenhæng mellem de to aspekter. En sådan analyse (ikke vist i tabel) bekræfter, at indslag, der fokuserede på personlige aspekter, meget ofte også var positive, mens indslag om proces og politik oftere var neutrale. Dette resultat hænger godt sammen med den eksisterede viden om traditionelle nyhedsudsendelser, der som nævnt på den ene side er klart mindre personfokuserede, men også klart mere neutrale overfor de medvirkende politikere, end

\section{Tabel 2}

Antal indslag i de tre analyserede programmer fordelt efter dominerende vinkling

\begin{tabular}{lccccc}
\hline & Proces & Person & Politik & Andet & I alt \\
\hline Go' morgen Danmark & 9 & 7 & 3 & 0 & 19 \\
\hline Go' aften Danmark & 0 & 11 & 1 & 2 & 14 \\
\hline Aftenshowet & 1 & 16 & 0 & 2 & 19 \\
\hline I alt & 10 & 34 & 4 & 4 & 52 \\
\hline
\end{tabular}


tilfældet var i 2007-valgkampens soft news-programmer. Samtidig understreger resultatet, at morgenprogrammet lignede de traditionelle nyhedsprogrammer mere end aftenprogrammerne.

\section{Konklusion og diskussion}

Overordnet viser vores analyse to ting: For det første balancerede de tre analyserede soft news-programmer de to store blokke i dansk politik relativt godt i 2007-valgkampagnen. Som forventet forekom der kun marginale mediebonusser til regeringsblokken i form af lidt større synlighed. På dette punkt adskiller soft newsprogrammerne sig ikke fra traditionelle tv-nyheder (Hopmann $e t$ al., Forthcoming). For det andet står det klart, at soft news-programmerne handlede om politikerne som personer og ikke deres politik eller det politiske spil. Samtidig er det tydeligt, at indslagene hovedsageligt anlagde en positiv tone overfor de medvirkende politikere. Begge dele står i skarp kontrast til de traditionelle fjernsynsnyheder, der i højere grad handler om politiske emner og i større omfang forholder sig neutralt til de medvirkende politikere (Hopmann et al., Forthcoming).

Det skal i den forbindelse nævnes, at supplerende analyser viser, at Go' morgen Danmark ligner de traditionelle nyhedsprogrammer mere end de to aftenprogrammer: I morgenudsendelserne var der således mere fokus på proces og politik, ligesom indslagene oftere var neutrale i tonen. Hvorfor morgen- og aftenprogrammerne var forskellige på denne facon, kan vi selvsagt kun gisne om på det foreliggende datagrundlag. Én grund kunne dog være, at morgenudsendelserne rettede sig mod et andet, mere nyhedsforbrugende publikum, hvilket fik dem at lægge mere vægt på informationsaspektet i forhold til underholdningsaspektet.

Hvor der formentlig er bred enighed om, at en nogenlunde balanceret dækning af forskellige regeringsalternativer er et gode set i et samfundsmæssigt perspektiv, kan man diskutere, hvorvidt de mange positive personhistorier i soft news-programmerne var til fordel for andet end politikernes egne imagekampagner. Umiddelbart kan man frygte, at programmerne har mistet deres informerende funktion til fordel for den underholdende funk- 
tion. Omvendt kan man argumentere for, at programmerne spillede en vigtig rolle, idet de gav begreberne politik og valgkamp et menneskeligt ansigt, hvilket kan være væsentligt for visse vælgergruppers demokratiske motivation.

Således konkluderer eksempelvis Baum (2003), at det let-identificerbare stof i soft news-genren appellerer til de såkaldt politisk usofistikerede vælgere, fordi de har lettere ved at identificere sig med politikerens hverdag og personlige egenskaber end abstrakte politiske ideer og komplekse sammenhænge. Sådanne vælgere interesserer sig derfor ikke for politik og følger ikke med i traditionelle nyheder. De bløde aktualitetsprogrammer kan derfor være deres eneste kilde til information om aktuelle politiske forhold, hvorved denne programtype får en særlig evne til at mobilisere en ellers demokratisk marginaliseret vælgergruppe. Dette sker vel at mærke uden at kompromittere den borgerlige oplysning hos de mere politisk vidende vælger, som forholder sig til politik på et højere abstraktionsniveau. Denne type vælgeres politiske ståsted påvirkes nemlig ikke af personskildringer, så der er groft sagt ikke overhængende fare for, at „de kloge“ vælgere bliver dummere af at se soft news. Men der er omvendt chancer for, at de mindre politisk sofistikerede bliver en anelse klogere på politik. I et moderne, oplyst folkestyre kan soft news-genren naturligvis ikke stå alene, men den kan været et fint supplement til den traditionelle nyhedsgenre, som ud fra et demokratisk ideal (fortsat) bør diskutere egentlige politiske sager i et sagligt og kritisk lys.

Afslutningsvis skal vi vende os mod spørgsmålet om, hvorvidt de fundne resultater kan generaliseres. Vi har studeret ét valg og én type programmer, så det forekommer oplagt at fremtidige studier kan undersøge soft news i andre medier, eksempelvis ugeblade, talkshows og gratisaviser. Vi har dog ikke nogen forventning om, at hverken vinkling eller tone vil være markant anderledes hér. Bevæger man sig derimod over i egentlige underholdningsprogrammer, som lader deltagerne danse, synge, spille fodbold, køre sære bilvæddeløb, bo i overvågende huse eller klare sig i vildmarken, giver det formentlig ikke megen mening at studere indholdet i medvirkendes udtalelser. I stedet kunne der sættes fokus på fordelingen af deltagere fra forskellige partier. At 
dømme efter den offentlige debat kan vores konklusion om balance ikke nødvendigvis udstrækkes til denne type af programmer, idet i hvert fald Dansk Folkeparti har følt sig forbigået (fx. Politiken, den 5. juli 2004). Man kunne også vælge at studere de bløde nyheder uden for valgkampsperioder, hvor medierne måske har lidt mindre fokus på en ligelig repræsentation af de forskellige partier (Walgrave \& van Aelst, 2006), men hvor vi ikke ser gode argumenter for at forvente anderledes tone eller vinkling $\mathrm{i}$ historierne, end vi har fundet i nærværende studie.

En helt tredje mulighed for fremtidig forskning er studier af effektspørgsmålet: Det vil være særdeles interessant at få klarlagt, om de ovenfor beskrevne vælgerdynamikker også gør sig gældende i dansk sammenhæng, og i hvilket omfang vælgerne rent faktisk anvender information fra henholdsvis bløde og hårde nyheder i deres partivalg. Mange spørgsmål står således stadig ubesvarede. Håbet er imidlertid, at nærværende analyse både kan tjene som afsæt for fremtidig forskning og i sig selv give indblik i indholdet af udvalgte, æterbårne soft news-programmer.

\section{N O TER}

1. Da nærværende analyse bygger på hele „populationen“ af soft newsprogrammer i valgkampen 2007 har vi gennem hele artiklen valgt ikke at afrapportere signifikanstests af forskelle mellem andele. Vi konkluderer ikke på baggrund af en stikprøve, og vi behøver derfor ikke tage højde for den fejlmargen, der vil være mellem stikprøve og population.

\section{REFEREN CER}

Andersen, Johannes \& Ole Borre (2007). „Partiledere gør en forskel“, pp. 289-306 i Jørgen Goul Andersen, Ole Borre, Kasper Møller Hansen \& Hans Jørgen Nielsen (red.), Det nye politiske landskab: Folketingsvalget 2005 i perspektiv, Århus: Academica.

Asp, Kent (2006). „Rättvisa nyhetsmedier. Partiskheten under 2006 års medievalrörelse“, JMG arbetsrapport, 42. årgang, nr.

Baum, Matthew A. (2003). "Soft News and Political Knowledge: Evidence 
of Absence or Absence of Evidence?" Political Communication, 20. årgang, nr. 2, pp. 173-190.

Berelson, Bernard (1952). Content Analysis in Communication Research, New York: Free Press.

Brants, Kees (1998). “Who's Afraid of Infotainment?” European Journal of Communication, 13. årgang, nr. 3, pp. 315-333.

Brants, Kees \& Peter Neijens (1998). “The Infotainment of Politics”, Political Communication, 15. årgang, nr. 2, pp. 149-164.

Brettschneider, Frank (2002). "Kanzlerkandidaten im Fernsehen - Häufigkeit, Tendenz, Schwerpunkte”, Media Perspektiven, nr., pp. 263276.

Bro, Peter (2008). “Normative Navigation in the News Media”, Journalism - Theory Practice and Criticism, 9. årgang, nr. 3, pp. 309-329.

Bro, Peter, Rasmus Jønsson, Søren Schultz Jørgensen \& Poul Anders Pedersen (2005). Mediernes valgkamp - et forsknings- og formidlingsprojekt om folketingsvalget 2005. Modinet Workingpaper, no. 16.

Bruun, Hanne (1999). Talkshowet-Portrcet af en tv-genre, Valby: Borgen.

Corner, John \& Dick Pels (2003). Media and the Restyling of Politics: Consumerism, Celebrity and Cynicism, London: Sage Publications.

Dahlgren, Peter (1995). Television and the Public Sphere: Citizenship, Democracy and the Media, London: Sage Publications.

Esser, Frank (1999). “'Tabloidization’ of News - A Comparative Analysis of Anglo-American and German Press Journalism”, European Journal of Communication, 14. årgang, nr. 3, pp. 291-324.

Fournier, Patrick, Richard Nadeau, André Blais, Elisabeth Gidengil \& Neil Nevitte (2004). "Time-of-voting Decision and Susceptibility to Campaign Effects”, Electoral Studies, 23. årgang, nr. 4, pp. 661-681.

Hjarvard, Stig (1999). TV-nyheder $i$ konkurrence, Frederiksberg: Samfundslitteratur.

Hjarvard, Stig (2008). En verden af medier. Medialiseringen af politik, sprog, religion og leg, Frederiksberg: Samfundslitteratur.

Hopmann, David Nicolas (2009). „Public service og politisk balance: En typologi“, Journalistica, nr. 1, pp. 5-27.

Hopmann, David Nicolas, Claes de Vreese \& Erik Albæk (Forthcoming). "Incumbency Bonus in Election News Coverage Explained: The Logics of Political Power and the Media Market." Journal of Communication. 
Jensen, Klaus Bruhn (red.) (2001). Dansk mediehistorie 3 (1953-1995), Frederiksberg: Samfundslitteratur.

Krippendorff, Klaus (2004). Content Analysis. An Introduction to its $\mathrm{Me}$ thodology, London: Sage Publications.

Krippendorff, Klaus \& Andrew F. Hayes (2007). "Answering the Call for a Standard Reliability Measure for Coding Data", Communication $\mathrm{Me}$ thods and Measures, 1. årgang, nr. 1, pp. 77-89.

Mancini, Paolo \& David Swanson (1996). "Politics, Media, and Modern Democracy: Introduction”, pp. 1-26 i David Swanson \& Paolo Mancini (red.), Politics, Media, and Modern Democracy. An International Study of Innovations in Electoral Campaigning and their Consequences, Westport: Praeger.

Mazzoleni, Gianpietro \&Winfried Schulz (1999). “'Mediatization’ of Politics: A Challenge for Democracy?” Political Communication, 16. årgang, nr. 3, pp. 247-261.

Negrine, Ralph \& Stylianos Papathanassopoulos (1996). "The 'Americanization' of Political Communication: A Critique”, Harvard International Journal of Press/Politics, 1. årgang, nr. 2, pp. 45-62.

Patterson, Thomas (1997). "The News Media: An effective Political Actor?” Political Communication, 14. årgang, nr. 4, pp. 445-455.

Patterson, Thomas (2000). "Doing Well and doing Good: How Soft News and Critical Journalism are Shrinking the News Audience and Weakening Democracy - And what News Outlets can do about It", Joan Shorenstein Center on the Press, Politics and Public Policy, nr.

Patterson, Thomas E. (1994). Out of Order, New York: Vintage Books.

Plasser, Fritz (2005). "From Hard to Soft News Standards? How Political Journalists in Different Media Systems Evaluate the Shifting Quality of News", The Harvard International Journal of Press/Politics, 10. årgang, nr. 2, pp. 47-68.

Ridout, Travis N. \& Michael Franz (2008). "Evaluating Measures of Campaign Tone”, Political Communication, 25. årgang, nr. 2, pp. 158-179.

Semetko, Holli A. (1996). "Political Balance on Television - Campaigns in the United States, Britain and Germany", The Harvard International Journal of Press/Politics, 1. årgang, nr. 1, pp. 51-71.

Shoenbach, Klaus, Jan De Ridder \& Lauf Edmund (2001). "Politicians on TV News: Getting attention in Dutch and German Election Campaigns”, European Journal of Political Research, 39. årgang, nr. 4, pp. 519-531. 
Strömbäck, Jesper (2008). "Four Phases of Mediatization: An Analysis of the Mediatization of Politics", The International Journal of Press/ Politics, 13. årgang, nr. 3, pp. 228-246.

Walgrave, Stefaan \& Knut de Swert (2002). “De kanseliersbonus in de Vlaamse pers. Een onderzoek naar regering en oppositie in drie Vlaamse kranten (1991-200o)", Tijdschrift voor Sociologie, 23. årgang, nr. 3/4, pp. 371-403.

Walgrave, Stefaan \& Peter van Aelst (2006). "The Contingency of the Mass Media's Political Agenda Setting Power: Toward a Preliminary Theory”, Journal of Communication, 56. årgang, nr. 1, pp. 88-109.

Weaver, David (red.) (1998). The Global Journalist. News People Around the World, Cresskill: Hampton Press.

Wien, Charlotte (2005). "Defining Objectivity within Journalism. An Overview", Nordicom Review, 26. årgang, nr. 2, pp. 3-15. 


\section{English Abstracts}

\section{Soft News in the 2007 Danish National Election: Balanced, but uncritical talk about People in Politics} CHRISTIAN ELMELUND-PRASTEKAER,

\section{LOUISE MÜLLER \& LOUISE NOWAK RASMUSSEN}

This article analyzes how political actors are presented in televised soft news during the Danish 2007 national election campaign. We expect a slight media bonus to the incumbent government and it's supporting parties as compared to the opposition. Moreover, we expect the tone towards the featured politicians to be positive. We also presume that the framing of the interviews will be predominantly focused at personality as opposed to game and issue framed. We conduct a quantitative content analysis of three different programs during three weeks prior to the Election Day in 2007. In total we study 52 individual soft news items of a total duration of seven and a half hour. We find support for all hypotheses and conclude that televised Danish soft news is fairly politically balanced and that it is almost always positive in the tone and about the lives, not the issues, of the interviewed politicians. 